$\underline{\text { Research Article }}$

\title{
Effect of Artemisia vulgaris Extract on Granzyme Expression and Tumor Mass Diameter (Study of Adriamycin Cyclophosphamide Chemotherapy in Adenocarcinoma Mammae C3H Mice Model)
}

\section{Pengaruh Ekstrak Artemisia vulgaris terhadap Ekspresi Granzyme dan Diameter Massa Tumor (Studi Pemberian Kemoterapi Adriamycin Cyclophosphamide Pada Model Adenokarsinoma Mammae Mencit C3H)}

\author{
Gery Rifano $\mathrm{H}^{1}$, Selamat Budijitno ${ }^{2}$, Hardian $^{3}$ \\ ${ }^{1}$ General Surgery Resident of RSUP dr. Kariadi Semarang \\ ${ }^{2}$ Staff on Oncology Surgery of RSUP dr. Kariadi Semarang \\ ${ }^{3}$ Staff on Physiology Faculty of Medicine Universitas Diponegoro Semarang
}

\begin{abstract}
Breast cancer incident continues to increase globally. The surgical management can be combined with other therapeutic modalities, including chemotherapy, radiation, and immunotherapy, such as Artemisia vulgaris (AV). This study aimed to determine the effect of AV extract on Granzyme expression and tumor mass diameter growth of $\mathrm{C} 3 \mathrm{H}$ mice with adenocarcinoma mammae. Twenty-four female $\mathrm{C} 3 \mathrm{H}$ mice were randomly divided into groups of $K$ (control), $P 1$ (AC chemotherapy), P2 (AV extract), and P3 (combination). Adenocarcinoma mammae were inoculated from donor mice. Two cycles of chemotherapy by Adriamycin $0.18 \mathrm{mg}$ and Cyclophosphamide $1.8 \mathrm{mg}$ were given intravenously, while Artemisia vulgaris $13 \mathrm{mg}(0.2 \mathrm{ml})$ was given orally once per day. Granzyme expression was assessed using immunohistochemical staining, while tumor mass diameter growth was measured using tumor calipers. There was a significant negative correlation between and tumor mass diameter growth ( $p=0,001$ and $r=-0,911)$. Artemisia vulgaris increases the apoptotic effects of Adriamycin-Cyclophosphamide chemotherapy by increasing Granzyme expression and decreasing tumor mass diameter growth in adenocarcinoma mammae $\mathrm{C} 3 \mathrm{H}$ mice.
\end{abstract}

Keywords: Adenocarcinoma mammae, Artemisia vulgaris, granzyme, tumor mass

\section{ABSTRAK}

Angka kejadian kanker payudara terus meningkat secara global. Tatalaksana bedah dapat dikombinasikan dengan modalitas terapi lainnya yaitu antara lain kemoterapi, radiasi, dan imunoterapi seperti Artemisia vulgaris (AV). Penelitian ini bertujuan untuk membuktikan efek ekstrak AV terhadap ekspresi Granzyme dan pertumbuhan diameter massa tumor adenokarsinoma mammae mencit $\mathrm{C} 3 \mathrm{H}$ ?HeJ. Dua puluh empat ekor mencit $\mathrm{C} 3 \mathrm{H}$ betina dibagi secara acak menjadi kelompok K (kontrol), P1 (kemoterapi AC.), P2 (ekstrakAV), dan P3 (kombinasi). Adenokarsinoma mammae berasal dari inokulasi mencit donor. Diberi 2 siklus kemoterapi Adriamycin 0,18 mg dan Cyclophosphamide 1,8 mg secara intravena. Artemisia vulgaris diberikan $13 \mathrm{mg}(0,2 \mathrm{ml})$ sekali sehari peroral. Ekspresi Granzyme dinilai dengan pengecatan imunohistokimia sedangkan pertumbuhan diameter massa tumor diukur dengan kaliper tumor. Hasil penelitian menunjukkan kombinasi kemoterapi dan ekstrak AV dapat memberikan gambaran ekstra granzyme yang paling tinggi, dan diameter tumor yang paling rendah pada tikus dengan inokulasi tumor. Didapatkan korelasi negatif kuat yang signifikan a antara ekspresi Granzyme dengan pertumbuhan diameter massa tumor ( $p=0,001$ dan $r=-0,911)$. Artemisia vulgaris meningkatkan efek apoptosis kemoterapi Adriamycin-Cyclophosphamide dengan meningkatkan ekspresi Granzyme dan menurunkan pertumbuhan diameter massa tumor pada adenokarsinoma mammae mencit $\mathrm{C} 3 \mathrm{H}$.

Kata Kunci: Artemisia vulgaris, adenokarsinoma mammae, ekspresi Granzyme, diameter massa tumor

Correspondence: Gery Rifano H. Department of Surgery, JI. DR. Sutomo No.16, Randusari, Kec. Semarang Sel., Kota Semarang, Jawa Tengah 50244 Tel.088215180805/(024)8413476 Email: geryrifano@gmail.com

DOI: http://dx.doi.org/10.21776/ub.jkb.2021.031.04.1 


\section{INTRODUCTION}

Breast cancer is cancer often found in women. Globally, the incidence of this disease continued to increase from 641,000 in 1980 to 1,643,000 cases in 2010 (1). By 2012, breast cancer was the $2^{\text {nd }}$ most significant cancer incidence in the world after lung cancer, reaching approximately 1.67 million cases. The incidence of this cancer is more common in developing countries than in developed countries. In Indonesia, it is estimated that the incidence of breast cancer is 40 among 100,000 women (2). Even though this cancer is primarily identical to women, it can also affect men with a frequency of approximately $1 \%$. More than $80 \%$ of patients come with advanced stages in Indonesia, making curative efforts more difficult (3).

Breast cancer treatment modalities include surgery, radiotherapy, cytostatic, immunotherapy, and hormonal therapy. The definitive local therapies that can be given are surgery and radiotherapy, while the systemic therapies can be chemotherapy, immunotherapy and hormonal therapy. In general, breast cancer chemotherapy is given in the form of a regimen (3).

There are various drug combinations in chemotherapy. The most common combinations are Fluorouracil, Adriamycin, and Cyclophosphamide (FAC); Fluorouracil, Epirubicin, and Cyclophosphamide (FEC); Adriamycin and Cyclophosphamide (AC) and Cyclophosphamide, Methotrexate, and Fluorouracil (CMF). Chemotherapy is given intermittently at an interval of three to four weeks. FAC, FEC, and CMF combination are given for six cycles (a period of 18 to 24 weeks), while $A C$ is given for two cycles (within a period of 6 weeks) (4).

Response Evaluation Criteria in Solid Tumors (RECIST) 1.1 is used to assess the success rate of therapy measured by the percentages of Complete Response (CR) and Partial Response (PR) or CR/PR. The percentage of CR/PR chemotherapy in breast cancer ranges from $20 \%$ to $40 \%$. However, chemotherapy also has adverse side effects, including toxic effects on the liver, kidneys, heart, and other organs of the body, as well as decreasing immune response (5).

Currently, cancer therapy research is focused on developing chemotherapy with lower toxicity effects by exploring new compounds that have anti-cancer properties, one of which is from medicinal plants. Various derivatives of medicinal plants have broad antibiotic and anti-malignant effects and have shown to be effective in overcoming multiple diseases (6).

There have been many studies on medicinal plants used as adjuvant chemotherapy, including the crown of Gods (Phaleria macrocarpa), black cumin (Nigella sativa), green tea (Camellia sinensis), soursop (Annona muricata) and mugwort (Artemisia vulgaris). In previous studies, the tumor-selective cytotoxic effects of Artemisia vulgaris could be used as an adjuvant in colorectal cancer, kidney cancer, prostate cancer, liver cancer, pancreatic cancer, skin cancer, and gastric cancer. Further evidence is still needed regarding the use of Artemisia vulgaris as an adjuvant chemotherapy medicinal plant for breast cancer (7).

In an initial study of Artemisia vulgaris, phenols, flavonoids, sesquiterpenoids (Artemisinin and its derivatives) and coumarin (scopoletin) were found. Artemisinin and its derivatives have been used as antimalarial drugs. In further studies, these substances show cytotoxic activity against cancer cells through the induction of apoptosis, inhibition of angiogenesis activity, disruption of the cancer cell cycle, and free radical toxicity. With these properties, Artemisinin can be used as an anti-cancer due to its selective toxic characteristics. These characteristics postulate that the side effects given are lower, making it safer for users. The selective cytotoxic nature of Artemisia vulgaris becomes a supporting factor for a preliminary study at the pre-clinical stage (8).

Apoptosis of tumor cells is triggered by NK cells and CTL cells. The cytotoxic effect on these two cells works by secreting perforin and Granzyme. Perforin will perforate the target cell membrane (tumor cells), becoming the entry path for Granzyme (serine esterase) into the cytosol. An apoptotic event then occurs as a result of the activity of these immune effector cells. The apoptosis of tumor cells will affect the tumor mass diameter growth $(9,10)$.

In cell growth physiology, apoptosis plays an equally important role as mitosis. Apoptosis shows a complementary role that has the opposite properties of mitotic mechanisms and cell proliferation. It is thought that apoptosis functions as a regulator in some cell populations to maintain body homeostasis. Cancer is an example of dysfunction in cell cycle regulation, in the form of the decreased mechanism of cell death with or without excess cell proliferation. In fact, the suppression of the apoptotic mechanism in the carcinogenesis process is thought to play an important role in increasing the size of several types of cancer (11).

This study aimed to determine the effectiveness of Artemisia vulgaris extract as an adjuvant for adenocarcinoma mammae chemotherapy of $\mathrm{C} 3 \mathrm{H}$ mice given Adriamycin Cyclophosphamide. The adjuvant effect was measured through the increase of Granzyme expression and the difference in tumor mass diameter growth. The results of this study are hoped to support the use of Artemisia vulgaris as adjuvant chemotherapy for breast cancer.

\section{METHOD}

\section{Research Design}

This study was a laboratory-experimental study with a posttest only control group design to measure Granzyme expression and a pretest and posttest control group design to measure the growth of tumor mass diameter. The four research groups were the control group $(\mathrm{K})$ that was mice inoculated with adenocarcinoma mammae lobular type cell, treatment group 1 (P1) was the same as the control group but was observed until a lump appeared and given AC chemotherapy. The next two groups received the same treatment as $\mathrm{P} 1$, but were given $100 \mathrm{mg} / \mathrm{kg} /$ day of Artemisia vulgaris extract (P2) and AC chemotherapy and Artemisia vulgaris 100 $\mathrm{mg} / \mathrm{kg} /$ day (P3).

\section{Experimental Animal}

$\mathrm{C} 3 \mathrm{H}$ mice were selected as the experimental subjects for this study. The mice were taken from rat breeders in Bogor. 
The inclusion criteria were female mice, eight weeks of age, $\mathrm{C} 3 \mathrm{H}$ strain, inoculated with adenocarcinoma mammae lobular type cells, weight 20-30 grams after acclimatization, and no anatomical abnormalities. The exclusion criteria were no tumor growth in the mice after inoculation, and if the mice experienced changes in behavior as indicated by inactive movements and sick during inoculation. The number of samples for each group was six mice, based on WHO criteria that the sample size for each group is at least five animals with a $10 \%$ reserve.

Artemisia vulgaris extract was made at LPPT I, Faculty of Medicine, Gajah Mada University. Treatment and tissue collection of mice were carried out at LPPT IV, Faculty of Medicine, Gajah Mada University. Paraffin block making, HE staining, and immunohistochemistry were carried out at the Anatomical Pathology Laboratory, Faculty of Medicine, Sebelas Maret University, Surakarta.

\section{AC chemotherapy and Artemisia vulgaris treatments}

A total of $24 \mathrm{C} 3 \mathrm{H}$ strain mice meeting the inclusion criteria were acclimatized for one week in the laboratory. Afterwards, the mice were inoculated with adenocarcinoma lobular type for one week. Of each inoculated mouse, tissue was then taken to detect breast cancer growth in the first week. After breast cancer growth was proven, mice were randomly divided into four groups through simple random sampling so that five mice were obtained for each study group. Each group was put in separate cages and uniformly received standard feed and drink ad libitum. The treatment was given according to the workflow. On the first day of treatment, AC chemotherapy and Artemisia vulgaris extract were given, and the diameter of the tumor mass was measured and then observed for three weeks. On week 3, the second dose of chemotherapy was given and monitored for another three weeks. After the $6^{\text {th }}$ week of the treatment, the diameter of the tumor mass was measured again. Termination of the mice was done by anesthetizing the mice with ether, and the mice were killed by dislocation. Further, the tumor tissues were taken, made into paraffin blocks, and processed for histological preparations.

\section{HE staining and immunohistochemistry}

Adenocarcinoma was fixed in buffered formalin solution ( $10 \%$ formalin solution in sodium acetate buffer until $\mathrm{pH}$ 7.0) for 18-24 hours. Then put the tissue in aqua dest solution for 1 hour. Next, put the tissue in the alcohol-xylol solution for 1 hour and then the pure xylol solution for $2 \mathrm{x}$ 2 hours. The tissue was put in liquid paraffin for $2 \times 2$ hours. Embed the tissue in solid paraffin and cut 6 microns thick with a microtome. The tissue pieces were attached to a slide with polylysine. Heat the slide in an incubator at 56$58^{\circ} \mathrm{C}$ until the paraffin melts. Sequentially, the tissue on the slide was put in Xylol I for 5 minutes, Xylol II for 5 minutes, absolute alcohol for $3 \times 2$ minutes, and then washed with running water for 2 minutes. Drop HE LilieMayer for 5 minutes and wash with running water for 2 minutes. Dip in acid alcohol 3 times then rinse under running water for 2 minutes. Dip the slide into saturated lithium carbonate 3 times and rinse under running water for 2 minutes. Put in alcohol $3 \times 2$ minutes, xylol $3 \times 5$ minutes, and eosin. Dip in $70 \%$ alcohol 3 times, then carbon xylol and xylol 3 times. Give xylol for 20 minutes and Canada balsam then cover with a deck glass.

Immunohistochemical staining with Streptavidin-Biotin.
Staining was carried out after the deparaffinization. Give sequentially xylol I for 5-10 minutes, xylol II 5-10 minutes, absolute alcohol for 10 minutes, 95\% alcohol for 5-10 minutes, $70 \%$ alcohol for 5-10 minutes then rinse by immersion in water for 1-2 minutes. Wash the slide by dipping it many times in phosphate buffer saline. Dry around the tissue with a rag. Give chromogen substrate to the preparation, perforin contained in the cytoplasm of CTL cells and NK cells will be brownish-red.

\section{Data Analysis}

The collected data were processed through data cleaning, coding, and tabulation. In the descriptive analysis, Granzyme expression and tumor mass diameter of adenocarcinoma mammae were presented in the form of mean, SD, median tables, and box plot graphs. The ShapiroWilk test was performed to determine data normality.

The One Way Anova test was used to test the hypothesis. The Post-Hoc test was conducted to determine the significance of the differences between groups. A correlation test was performed between the Granzyme expression and the tumor mass diameter growth variables using the Pearson correlation test. Data analysis was done using SPSS Ver. 21.0 for Windows.

\section{Research Ethical Requirements}

This research applied animal ethics in managing the experimental animals. The research has been approved by the Ethics Committee for Health Research, Faculty of Medicine, Diponegoro University. All experimental animals were cared for and managed according to animal maintenance standard.

\section{RESULTS}

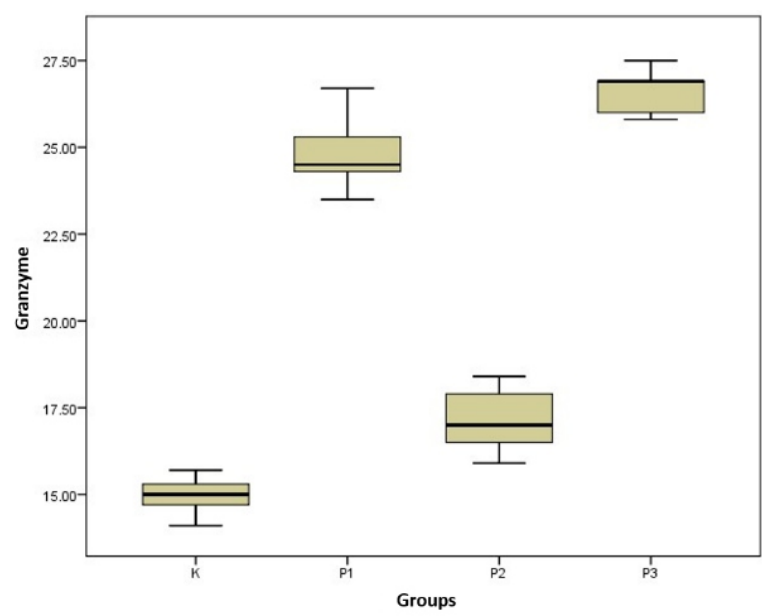

Figure 1. The average of Granzyme expression. The average of granzyme expression shown in mean \pm SD in control group (K), AC chemotherapy treatment (P1), AV treatment (P2), and Combination of CA + AV (P3) were $14.96 \pm 0.60 ; 24.86 \pm$ $1.21 ; 17.14 \pm 1.01$; and $26.90 \pm 0.70$, respectively

Granzyme expressions were found higher in P3 (combination) and P1 (chemotherapy) groups than that in P2 (extract) group. Analysis of differences in Granzyme expression between groups using the One-Way ANOVA test and followed by the Post Hoc test showed a significant difference, proving that the treatment resulted in differences in Granzyme expression. 


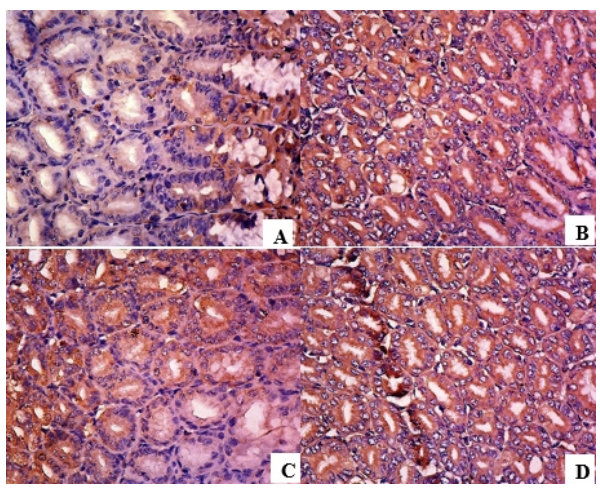

Figure 2. Microscopic view of Granzyme IHC stain. A. Control group (K); B. Treatment group 1 (P1); C. Treatment group 2 (P2); D. Treatment group 3 (P3)

Table 1. Post Hoc analysis of Granzyme expression between groups

\begin{tabular}{ccccc}
\hline & Group & P1 & P2 & P3 \\
\hline K & 0,010 & 0,001 & & 0,001 \\
P1 & $0,47-$ & 0,001 & 0 \\
P2 &, 01 & - & 00 \\
\hline
\end{tabular}

*Tested using Bonferroni (significant $p<0,05$ )

From the results of the Bonferroni test, the expression of Granzyme in all treatment groups was higher when compared to control. Administration of chemotherapy alone (P2) essentially gave lower results compared to conditions of tumor (P1) and tumor given chemotherapy combination (P3). Overall, chemotherapy combination (P3) in tumor-inoculated mice showed the highest and statistically significant granzyme expression.

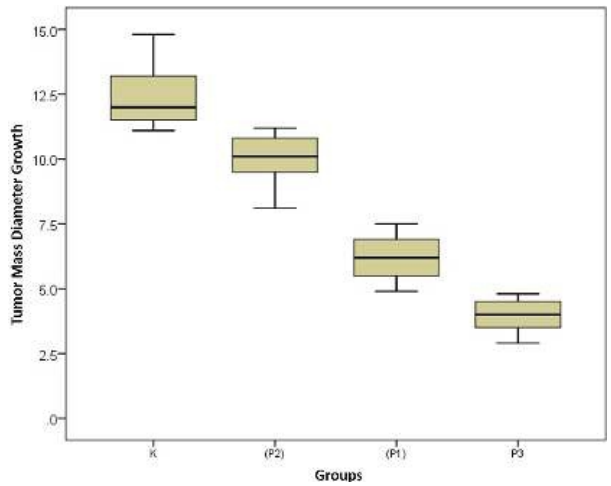

Figure 3. The average growth of tumor mass diameter. The average growth of tumor mass diameter shown in mean \pm SD in in control group (K), AC chemotherapy treatment (P1), AV treatment (P2), and Combination of CA + AV (P3) were 12,52 $\pm 1,49 ; 6,20 \pm 1,04 ; 9,94 \pm 1,21$; and $3,94 \pm 0,76$, respectively

The average growth of tumor mass diameter was found lower in P3 (combination) and P1 (chemotherapy) groups than in the P2 (extract) group. Analysis of differences in the growth of tumor mass diameter between groups using the One-Way ANOVA test followed by the Post Hoc test proved differences in the tumor mass diameter (getting smaller) with treatment. A combination of chemotherapy and artemisinin extract administration resulted in the smallest tumor diameter.

Correlation between Granzyme expression and tumor mass diameter growth

A correlation test between Granzyme expression and tumor mass diameter growth was done in P3 group (combination). The data normality test for both variables was conducted using the Shapiro-Wilk test. From this test, normal data were obtained ( $p>0.05$ ), so the correlation analysis was continued using the Pearson test. Granzyme expression negatively correlates with tumor mass diameter growth $(R=-0.911)$ with $p$-value 0.001

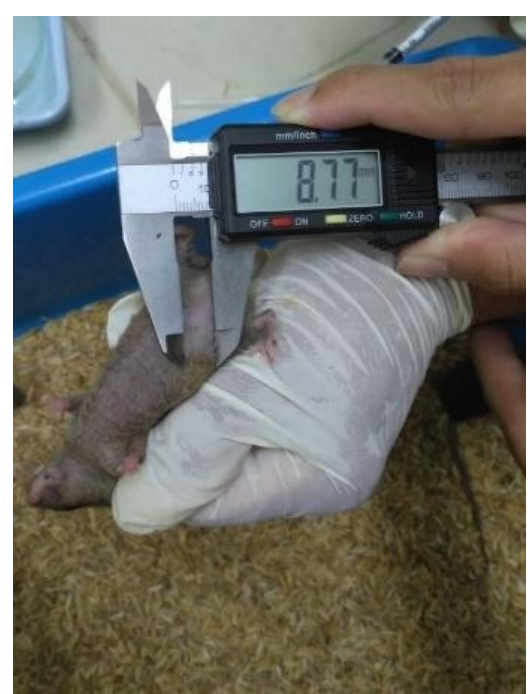

Figure 4. Measurement of the diameter of the tumor mass

\section{DISCUSSION}

This research aimed to prove the effect of Artemisia vulgaris extract administration in $\mathrm{C} 3 \mathrm{H}$ mice with adenocarcinoma mammae given AdriamycinCyclophosphamide chemotherapy measured by Granzyme expression and tumor mass diameter growth. The results showed that administration of Artemisia vulgaris extract and its combination with chemotherapy provided higher granzyme expression and smaller tumor mass diameter compare with group with AC chemotherapy and artemisia vulgaris alone. This data shown that-Granzyme expression negatively correlates with tumor mass diameter growth which means that if the expression of Granzyme increases, the growth of the diameter of the tumor mass will decrease

Artemisia vulgaris extract and its combination with chemotherapy have been shown to provide higher granzyme extract than untreated tumor conditions. Artemisinin compound in Artemisia vulgaris significantly increases NK cell cytotoxic activity through exocytosis granules containing Granzyme (12). Granzyme is $90 \%$ of total cytolytic granule mass, especially secretory lysosome from CTL and NK cells. CTL cells and NK cells release poreforming protein or perforin (cytolysin) and serine protease 
(Granzyme) group enzymes from their cytotoxic granules, which activate secretory, induce caspase as a weapon against cancer cells (13).

These granules envelop the target cells (tumor cells) and fuse with the target cell membrane (exocytosis). NK cell granules contain perforin, cytotoxins, serine esterase (Granzyme) and proteoglycans. Perforin perforates the target cell membrane, which then becomes the entrance pathway of other cytotoxic molecules into the cytoplasm and nucleus of the cell, thereby inducing the death of the target cell. Granzyme can activate endogenous procaspase in target cells. The apoptotic mechanism is also regulated by caspase activity. Caspase later activates DNAase and induces DNA damage during apoptosis so that the organelle and nucleus of the cell shrink and affect the size of the tumor mass. When the Granzyme expression increases, the tumor mass diameter growth will decrease $(13,14)$. This results are in line with our results that revealed a significant negative relationship between granzyme expression and tumor mass diameter.

Adriamycin Cyclophosphamide chemotherapy is given in 2 cycles over a six-week periods. The AdriamycinCyclophosphamide combinations are commonly used as chemotherapy for breast cancer. The use of Adriamycin in combination with other agents increase the clinical response and decrease the side effects were compared with Adriamycin alone $(15,16)$. Adriamycin interacts with DNA, directly influencing transcription and replication. Adriamycin is able to form a tripartite complex with topoisomerase II and DNA. Topoisomerase II is an ATPdependent enzyme that works by binding to DNA. This binding causes a double-strand break at the 3'phosphate end that allows strand exchange to occur and straightens the supercoiled DNA. These straight strands can then be linked to the DNA strand by topoisomerase II. Topoisomerase is very useful for DNA replication and repair. The formation of the tripartite complex will inhibit the splicing process of the DNA strand so that the cell cycle can stop in the $\mathrm{G} 1$ and $\mathrm{G} 2$ phases and spur the occurrence

\section{REFERENCES}

1. Forouzanfar MH, Foreman KJ, Delossantos AM, et al. Breast and Cervical Cancer in 187 Countries between 1980 and 2010: A Systematic Analysis. Lancet. 2011; 378(9801): 1461-84.

2. Mugi W. Deteksi Dini Kanker Leher Rahim dan Kanker Payudara di Indonesia 2007-2014. In: Kementerian Kesehatan RI (Ed). Buletin Jendela Data dan Informasi Kesehatan. Jakarta: Kementerian Kesehatan Republik Indonesia; 2015: p. 12-15.

3. Kementerian Kesehatan Republik Indonesia. Panduan Nasional Penanganan Kanker (Kanker Payudara). Jakarta: Komite Nasional Penanggulangan Kanker; 2015: p. 1-10.

4. Azwardi R. Perkembangan Mutakhir Tumor Ganas Payudara. Universa Medicina. 2005; 24(4): 190197.

5. Luangdilok S, Samarnthai N, and Korphaisarn K. Association between Pathological Complete Response and Outcome Following Neoadjuvant Chemotherapy in Locally Advanced Breast Cancer Patients. Journal of Breast Cancer. 2014; 17(4): 376- of apoptosis. It can be concluded that disruption in the double-strand DNA repair system will trigger cell damage (15).

The combination of Adriamycin Cyclophosphamide is polyfunctional in killing the cells. Cyclophosphamide agent can enter the DNA metabolic loop and then stop the metabolism and RNA transcription, breaking the nucleic acid fusion chain (17). The significant increase in Granzyme expression was only found in the combination group compared to the chemotherapy group. It shows that the Artemisia vulgaris extract increases the cytotoxic activity of chemotherapy against tumor cells (18).

This research used the size of the tumor mass diameter. The European cancer research group used the maximum tumor diameter as a criterion for evaluating the therapeutic response in solid tumors. However, it is necessary to consider the tumor load measurement generally represented by the measurement of tumor volume which is a critical factor in determining the prognosis. Other studies indicated that the maximum diameter of the tumor is correlated with the number of positive lymph nodes which show an association with lymphatic and distant metastases $(18,19)$.

This study proves that Artemisia vulgaris extract has the potential as an immunomodulator as an adjunct to primary therapy as indicated by higher Granzyme expression contributed to tumor mass diameter.

In conclusion, we have shown that the combination of Adriamycin-Cyclophosphamide chemotherapy and Artemisia vulgaris extract in the adenocarcinoma mammae $\mathrm{C} 3 \mathrm{H}$ mice model enhances Granzyme expression and reduce the tumor mass diameter growth. There is a significant correlation between increased Granzyme expression and decreased tumor mass diameter growth in the adenocarcinoma mammae $\mathrm{C} 3 \mathrm{H}$ mice model given a combination of Adriamycin-Cyclophosphamide chemotherapy and Artemisia vulgaris extract.

385.

6. Das AK. Anticancer Effect of AntiMalarial Artemisinin Compounds. Annals of Medical and Health Sciences research. 2015; 5(2): 93-102.

7. Haniya AK and Padma PR. Phytochemical Investigation of Methanolic Extract of Artemisia Vulgaris L. Leaves. International Journal of Pharma and Bio Science. 2014; 5(2): 184-195.

8. Yance DR, Sagar SM. Targeting Angiogenesis with Integrative Cancer Therapies. Integrative Cancer Therapies. 2006; 5(1): 9-29.

9. Jianguang J, Yiyu $\mathrm{Q}$, Ligong $\mathrm{Z}$, et al. Artemisinin Inhibits Gallbladder Cancer Cell Lines Through Triggering Cell Cycle Arrest and Apoptosis. Molecular Medicine Reports. 2016; 13(5): 4461-8.

10. Abbas A, Lichtman AH, and Pillai S. Cellular and Molecular Immunology. 6th ed. Philadelphia: Elseiver-Saunders; 2007: p. 3-15, 65-80, 275-289, 314-316, 391-410.

11. Elmore S. Apoptosis: A Review of Programmed Cell Death. Toxicologic Pathology. 2007; 35(4): 495-516. 
12. Houh YK, Kim KE, Park S, et al. The Effects of Artemisinin on the Cytolytic Activity of Natural Killer (NK) Cells. International Journal of Molecular Sciences. 2017; 18(7): 1-11.

13. Roitt IM and Delves PJ. Roitt's Essential Immunology. 10th edition. Massachusetts: Blackwell Science; 2001: p. 137-139.

14. Abbas AK, Lichtman AH, and Pillai S. Cellular and Mollecular Immunology. 8th edition. Philadelphia: Saunders Elsevier; 2015: p. 383-397.

15. Hermawan A and Sarmoko. Doxorubicin Cancer Chemoprevention Research Center Farmasi UGM. ( O n I i n ) 4 F e b r u a r i 2011 . ccrc.farmasi.ugm.ac.id/?page_id=2246 [diakses tanggal 10 Oktober 2017].

16. Jankowitz RC and Davidson NE. Breast Cancer. In: Boyiadzis MM, Frame JN, Kohler DR, and Fojo T
(Eds). Hematology-Oncology Therapy. 2nd edition. New York: McGraw-Hill Education; 2014: p. 102

17. Fleming RA. An Overview of Cyclophosphamide and Ifosfamide Pharmacology. Pharmacotherapy. 1997; 17(5): 146-154.

18. Johnson CR, Thames HD, Huang DT, and SchmidtUllrich RK. The Tumor Volume and Clonogen Number Relationship: Tumor Control Predictions Based Upon Tumor Volume Estimates Derived From Computed Tomography. International Journal of Radiation Oncology, Biology, Physics. 1995; 33(2): 281-287.

19. Therasse P, Arbuck SG, Eisenhauer EA, et al. New Guidelines to Evaluate the Response to Treatment in Solid Tumors. European Organization for Research and Treatment of Cancer, National Cancer Institute of the United States, National Cancer Institute of Canada. Journal of the National Cancer Institute. 2000; 92(3): 205-216 